Kajian Jurnalisme

ISSN 2549-0559 (cetak) ISSN 2549-1946 (online)

Volume 03 Nomor 01 Tahun 2019

\title{
Persepsi Khalayak Terhadap Radio Komunitas Kampus 107.8 Mandalla FM
}

\author{
Shabrina Pramudita Pavitasari, Efi Fadilah, Ika Merdekawati Kusmayadi \\ Econusa (NGO), Jakarta \\ E-mail: shabrinapp@yahoo.com
}

\begin{abstract}
Community radio presents as a part of the distribution of information needs in line with the growth of democracy in Indonesia. Radio Mandalla, 107.8FM, is a campus radio managed by campus to encounter the campus need in disseminating information. Uniquely, this community radio claims to be Dakwah Radio, which is spreading the information on Islamic themes. This research tries to seek the perceptions of the audiences towards Radio Mandalla, in encountering the uses and gratification of the media by the audiences. This research applies a descriptive survey method with a quantitative approach. The primary data of this research obtains from the result of questionnaires spread to 41 respondents in total using purposive sampling. The result indicates that more than $50 \%$ of the audience grants a high amount of appreciation because the radio can provide their needs and satisfactions of the information. The audience utilizes Radio Mandalla as a media in seeking information, a medium of interaction, and strengthen the existence of minority groups in the society. Besides, Radio Mandalla is one of the community media that still perform well its role and function, which are from the community, by the community and for the community.
\end{abstract}

Keywords: audience perception, community radio, campus radio, mass media,

\begin{abstract}
Abstrak
Radio komunitas hadir sebagai bagian dari pemerataan kebutuhan informasi sejalan dengan demokrasi yang semakin tumbuh. Radio Mandalla 107.8 FM, adalah radio komunitas kampus yang dikelola oleh kampus untuk memenuhi kebutuhan kampus dalam penyebaran informasi. Uniknya radio komunitas ini mengklaim sebagai radio dakwah, yaitu menyebarkan informasi yang bertemakan Islam. Penilitian ini ingin mengetahui persepsi khalayak terhadap Radio Mandalla, dalam memenuhi kebutuhan dan kepuasan khalayaknya. Penelitian ini menggunakan metode survei deskriptif dengan pendekatan kuantitatif. Data primer penelitian ini diperoleh dari hasil kuesioner kepada responden berjumlah 41 orang dengan menggunakan teknik berdasarkan tujuan. Hasil penelitian ini menunjukkan lebih dari 50\% khalayak memberi nilai cukup tinggi kepada Radio Mandalla karena kebutuhan dan kepuasan mereka terhadapat informasi yang diberikan media tersebut terpenuhi. Khalayak menggunakan Radio Mandalla sebagai media untuk mencari informasi, sebagai media interaksi, dan penguatan eksistensi kelompok minoritas dalam masyarakat. Selain itu, Radio Mandalla merupakan salah satu media komunitas yang masih menjalankan peran dan fungsinya dengan baik, yakni dari, oleh, untuk komunitas.
\end{abstract}

Kata kunci: media massa, persepsi khalayak, radio kampus, radio komunitas 
95 | Kajian Jurnalisme

ISSN 2549-0559 (cetak) ISSN 2549-1946 (online)

Volume 03 Nomor 01 Tahun 2019

\section{Pendahuluan}

Radio merupakan salah satu bentuk media massa. Radio merupakan buah perkembangan teknologi yang memungkinkan suara ditransmisikan secara serempak melalui gelombang elektromagnetik di udara. Radio biasanya menyiarkan berita, iklan, musik, sampai diskusi dan drama. Radio adalah pemancar gelombang elektromagnetik yang membawa muatan sinyal suara, yang terbentuk melalui microphone, kemudian pancaran ini diterima oleh sistem antena untuk diteruskan ke pesawat penerima dan sinyal radio itu diubah menjadi suara atau audio di dalam loudspeaker (Wahyudi, 1996).

Radio dibagi tiga macam, yakni radio pemerintah, radio swasta, dan radio komunitas. Radio pemerintah adalah radio yang didirikan oleh negara yang pengelolaannya bertumpu pada anggaran negara. Radio swasta atau komersial memiliki definisi yang hampir sama dengan radio komunitas maupun radio pemerintah, akan tetapi yang membedakan pada sisi komersialnya. Radio komersial adalah radio yang didirikan oleh pemilik modal yang merupakan radio berorientasinya selalu didasarkan pada faktor profit. Radio komunitas adalah stasiun siaran radio yang dimiliki, dikelola, diperuntunkan, dan didirikan oleh sebuah komunitas. Radio komunitas juga sering disebut sebagai radio sosial, radio pendidikan, atau radio alternatif.

Radio komunitas pertama muncul di Bolivia, Amerika Latin periode tahun 1947, yaitu radio buruh tambang yang menyiarkan problem kemiskinan. Kemudian berkembang pula di Kolumbia dan berbagai negara. Sementara di Indonesia, pada masa penjajahan Jepang radioradio yang mulanya berbasis komunitas ini dikuasai Jepang dan diubah nama serta statusnya menjadi Hosokyoku. Hanya saja setelah pasca kemerdekaan, Hosokyoku berubah nama menjadi Radio Republik Indonesia (RRI) pada 11 September 1945. Setelah itu muncullah PP Nomor 55 Tahun 1970 tentang Radio Siaran Non Pemerintah tertanggal 17 Desember. Radio yang semula berbasis komunitas berubah menjadi PT, yang berarti asas komunitas berubah menjadi komersial (Haryanto \& Ramdojo, 2009). Hal tersebut menunjukkan keberadaan radio komunitas menjadi tidak terdeteksi atau tidak mendapatkan tempat.

Pemerintahan Orde Baru menghasilkan UU No. 24 Tahun 1997 tentang penyiaran, namun posisi radio komunitas masih tidak jelas. Lalu, pada tahun 2000 keberadaan radio komunitas akhirnya mendapat pengakuan dari pemerintah secara formal dengan munculnya rancangan Undang-Undang Penyiaran, yang kemudian disahkan menjadi Undang-Undang Penyiaran No. 32 tahun 2002 tentang perlu dibentuknya Komisi Penyiaran Indonesia (KPI) baik tingkat pusat maupun provinsi. Di tahun 2003 terbentuklah KPI pusat dan tahun 2004 terbentuklah Komisi Penyiaran Indonesia Daerah (KPID) di provinsi Jawa Timur, Jawa Tengah, dan Jawa Barat (Nasution, 2012). Jawa Barat secara kuantitas mempunyai jumlah terbanyak untuk radio komunitas dibandingkan dengan provinsi lain (Rachmiatie, 2007:8990).

Setelah disahkannya disahkannya Undang-undang No. 32 Tahun 2002 tentang penyiaran pasal 21, eksistensi radio komunitas di Indonesia semakin kuat. Disebutkan pada pasal tersebut bahwa lembaga penyiaran yang berbentuk badan hukum Indonesia didirikan oleh komunitas tertentu, bersifat independen, dan tidak komersil dengan daya pancar rendah, luas 
jangkauan wilayahnya terbatas, serta untuk melayani kepentingan komunitasnya. Setelah jatuhnya Rezim Orde Baru, hingga setelah diberlakukannya UU No.32 Tahun 2002, radio komunitas seperti ini semakin menjamur (Gazali, 2002: 78-80).

Radio Komunitas hadir untuk melayani kepentingan komunitasnya, karena radio komunitas dibiayai juga oleh komunitas. Penyiaran pada radio komunitas mewakili semua lapisan masyarakat yang terdapat dalam komunitas yang bersangkutan secara merata dan demokratis, maka dari itu radio komunitas adalah media yang dimiliki, dikelola, dari, untuk dan oleh komunitas (Susilo, 2016). Salah satu tujuan kehadiran radio komunitas adalah untuk memberikan keragaman kepemilikan (diversity of ownership) dan keragaman isi siaran (diversity of content) agar isi siaran tidak didominasi oleh siaran terpusat. Contoh persoalan dari siaran televisi di Indonesia yang lebih banyak didominasi oleh televisi Jakarta juga menjadi gambaran akan terjadinya persoalan serupa pada dunia siaran radio. "Kematian" televisi lokal ternyata mengundang keprihatinan dari masyarakat di daerah yang mengeluh siaran televisi terlalu berbau Jakarta, mengabaikan nilainilai lokal (local wisdom) sebagaimana dicita-citakan UU Penyiaran (Sjuchro, 2017).

Pada kenyataannya, banyak radio komunitas yang belum memiliki izin resmi. Hal tersebut disebabkan oleh faktor sulitnya mengurus perizinan di pemerintah. Selain itu, radio komunitas juga jarang yang ada dikelola dengan serius. Hal ini diperkuat dengan pernyataan Dian, yang menyebutkan bahwa sangat jarang (bahkan mungkin tidak pernah ada) radio komunitas yang dikelola dengan serius, meskipun antusiasme untuk mendirikan lembaga penyiaran alternatif tersebut sangat tinggi (Sjuchro, 2018). Radio mempunyai kebebasan untuk berekspresi dibandingkan radio swasta, sehingga radio komunitas mempunyai kesempatan sangat terbuka lebar untuk lebih dekat dengan pendengarnya.

Menarik untuk meneliti radio komunitas di Kota Bandung, terutama radio komunitas berbasis kampus karena kepentingan siaran radio komunitas kampus lebih mengacu pada pemenuhan aspirasi publik mahasiswa yang heterogen, bukan untuk kepentingan komersial. Radio mahasiswa juga ikut membentuk model komunikasi yang terbuka dan demoktratis di kota-kota pendidikan siaran mahasiswa dan akademisi kampus yang mengusung suara-suara kritis dan konstruktif terhadap pembangunan. Selain itu, radio komunitas di Bandung memiliki lembaga resmi yang menaunginya, yakni Forum Radio Kampus Bandung (FRKB). Radio komunitas berbasis kampus yang sudah memiliki izin resmi dari KPID dan terdaftar sebagai anggota FRKB, salah satunya adalah radio komunitas Mandalla 107.8 FM di Universitas Islam Negeri Sunan Gunung Djati Bandung (UIN SGD).

Radio komunitas Mandalla adalah radio kampus yang berfungsi sebagai sarana dakwah dari, oleh, dan untuk masyarakat, serta sebagai sarana praktek bagi mahasiswa Fakultas Dakwah dan Komunikasi UIN SGD Bandung. Radio mandala juga hadir dengan nuansa religius dan intelektual sebagai bagian dari bentuk karakter dan jati diri yang dapat membedakan dari radio-radio siaran lainnya, sebagaimana karakteristik dari radio komunitas. Media massa mempunyai kekuatan untuk mempengaruhi khalayak, namun manusia dengan sifatnya yang selektif tetap berperan dalam pemilihan media. Khalayak mempunyai motif dalam memilih media yang sesuai dengan kebutuhannya (Tanta, Mihovilović, \& Sablić, 2014). 
97 | Kajian Jurnalisme

ISSN 2549-0559 (cetak) ISSN 2549-1946 (online)

Volume 03 Nomor 01 Tahun 2019

Khalayak yang memilih mendengarkan radio komunitas kampus merupakan salah satu motif seseorang untuk memenuhi kebutuhan informasinya.

Penelitian ini menggunakan metode penelitian survei deskriptif dengan menggunakan pendekatan kuantitatif. Pendit menyatakan bahwa penelitian dengan menggunakan pendekatan kuantitatif memungkinkan peneliti untuk memahami gejala dengan lebih mendalam dengan cara setiap hal yang diteliti harus dapat diidentifikasi, dikategorisasikan, dan diidentifikasikan secara jelas untuk kemudian dapat diukur melalui cara-cara yang tepat (Pendit, 2003,:96).

Maka dari itu, penelitian bermaksud untuk mengumpulkan data dan menggambarkan suatu gejala yang sudah ada, yaitu bagaimana persepsi khalayak kepada radio komunitas 107.8 Mandalla FM dengan metode survei deskriptif. Tujuan dari penelitian ini adalah untuk mengetahui pola konsumsi khalayak radio komunitas 107.8 Mandalla FM, untuk mengetahui penilaian khalayak tentang produk Radio Komunitas 107.8 Mandalla FM menurut isi dan kemasannya, serta untuk mengetahui tingkat kepuasan khalayak Radio Komunitas 107.8 Mandalla FM.

\section{Metode}

Metode penelitian yang dipakai dalam penelitian ini adalah metode survei deskriptif dengan pendekatan kuantitatif. Metode survei menjadi metode yang digunakan, sebab penelitian survei memungkinkan penggeneralisasian sebuah gejala sosial tertentu kepada gejala sosial dengan populasi yang lebih besar karena survei tidak mempertahankan keutuhan dari subjek yang diteliti. Responden dalam hal ini menjadi kesatuan yang utuh, dan menjadi bagian yang dianalisis yang dapat diidentifikasikan dan dikategorisasikan secara jelas yang kemudian diukur menggunakan alat ukur yang tepat (Bungin, 2011; Pendit, 2003)

Penelitian dengan menggunakan penelitian deskriptif dilakukan untuk memberikan gambaran yang lebih detil mengenai suatu gejala atau fenomena. Penelitian ini diidentifikasikan dengan penelitian yang menggunakan pertanyaan "bagaimana" dalam mengembangkan informasi yang ada. Selain itu, penelitian ini lebih ditekankan kepada menggambarkan pola suatu gejala jika gejala tersebut memang sudah tereksplorasi. Tujuan dari penelitian deskriptif ini adalah menggambarkan mekanisme sebuah proses dan menciptakan seperangkat kategori atau pola (Prasetyo \& Jannah, 2008: 42-44)

Selanjutnya, peneliti akan menggunakan teori uses and gratification. Teori ini bukanlah sebuah teori yang berbicara mengenai bagaimana media massa memengaruhi khalayak, tapi teori ini berbicara mengenai bagaimana khalayak menggunakan media massa. Rakhmat menjelaskan uses and gratification tidak tertarik membahas apa yang dilakukan oleh media massa kepada khalayak, tetapi ia lebih tertarik apa yang dilakukan khalayak terhadap media massa (Rakhmat, 2014).

Dalam teori ini, khalayak media massa dianggap sebagai khalayak yang aktif dalam menggunakan media massa (khususnya radio komunitas kampus) dengan tujuan memenuhi kebutuhannya. Berdasarkan teori uses and gratification terdapat lima asumsi asal, yaitu komunikasi massa berguna oleh manusia (utility); konsumsi media diarahkan oleh motif 
Kajian Jurnalisme

ISSN 2549-0559 (cetak) ISSN 2549-1946 (online)

Volume 03 Nomor 01 Tahun 2019

(intentionality); perilaku penggunaan media massa mencerminkan kepentingan dan preferensi (selectivity); dan khalayak sebenarnya kepala batu (stubborn) (Blumler, 1979).

Data dikumpulkan dengan menggunakan kuesioner dengan teknik purposive sampling, yaitu memilih orang-orang tertentu, berdasarkan penelitian tertentu dianggap dalam mewakili statistic, tingkat signifikansi, dan prosedur hipotesis tidak berlaku bagi rancangan sampling non-probabilitas. Dengan pertimbangan, yakni pernah mendengarkan Radio Mandalla dengan mengajukan pertanyaan saringan terhadap pola mendengarkan rakom 107.8FM Mandalla UIN, dengan sampel pendengar rakom kampus tersebut berjumlah 41 orang.

Pada penelitian ini, peneliti akan meneliti bagaimana pola konsumsi khalayak terhadap radio komunitas kampus dan tingkat kepuasan khalayak radio komunitas kampus menurut khalayaknya dengan menggunakan teori uses and gratification. Dengan begitu peneliti akan mendapatkan kebutuhan, kepentingan, selera khalayak, dan juga seberapa puas khalayak menggunakan radio komunitas 107.8 Mandalla FM.

\section{Hasil dan Pembahasan}

Hasil penelitian mendeskripsikan profil pendengar Radio Mandalla 107.8 FM Universitas Islam Negeri Sunan Gunung Djati (UIN SGD), Bandung. Presentase tertinggi responden berdasarkan usia adalah kelompok usia 19 - 23 tahun sebesar 70.7\% disusul oleh kelompok usia 24 - 28 tahun sebesar 26.8\%. Data ini menggambarkan bahwa kelompok usia yang paling sering mendengarkan Radio Mandalla adalah berada pada rentang 19 hingga 28 tahun yang merupakan kelompok usia mahasiswa dan kelompok usia produktif. Sedangkan untuk profil pendengar berdasarkan pendidikan, 100\% responden adalah lulusan SMA yang sekarang sedang menjalani studi di jenjang S1. Tingkat pendidikan perlu diketahui sebab tingkat pendidikan dapat menjadi salah satu ukuran kebutuhan kognisi setiap responden. Radio komunitas memiliki keunikan, yaitu bersifat independen, tidak komersial, daya pancar rendah $(50 \mathrm{KW})$, luas jangkauan wilayah terbatas $(2 \mathrm{KM})$, dan untuk melayani kebutuhan komunitas (Rachmiatie, 2007). Maka dari itu, responden adalah mahasiswa dari UIN SGD, yaitu khalayak yang mendengarkan Radio Mandalla 107.8 FM.

Sementara itu berdasarkan asal fakultas, responden Mandalla FM adalah mahasiswa dari Fakultas Dakwah \& Komunikasi, yaitu 80.5\%, 33 responden dari total 41 responden. Mahasiswa fakultas Ushluddin tidak ada yang mendengarkan Radio Mandalla, sebanyak 2 orang (4.9\%) dari fakultas Tarbiyah \& Keguruan dan Sains \& Teknolgi, dari beberapa fakultas, yakni fakultas Syariah \& Hukum, Adab \& Humaniora, Psikologi, dan FISP hanya 1 orang (2.4\%) yang mengonsumsi atau mendengarkan Radio Mandalla. Hal ini sangat wajar, karena Radio Mandalla dikelola oleh laboratorium dari Fakultas Dakwah \& Komunikasi, selain itu radio komunitas ini juga dimanfaatkan oleh Fakultas tersebut untuk menjadi medium bagi mahasiswa membuat konten dakwah yang disebarkan melalui media radio. Asal fakultas menjadi penting untuk diketahui untuk dapat menunjukkan besaran kebutuhan informasi yang dibutuhkan oleh khayalak. 
99| Kajian Jurnalisme

ISSN 2549-0559 (cetak) ISSN 2549-1946 (online)

Volume 03 Nomor 01 Tahun 2019

\section{Pola Konsumsi Khalayak Radio Mandalla}

Khalayak aktif memilih media yang dikonsumsinya sesuai dengan kebutuhannya untuk memenuhi kepuasan dirinya akan memperoleh informasi. Untuk mengetahui pola konsumsi konsumsi khayalak dalam mendengarkan Radio Mandalla, perlu diketahui jenis media yang digunakan, frekuensi mendengarkan, durasi lama mendengarkan serta konten-konten apa saja yang dikonsumsi oleh pendengar Radio Mandalla, yaitu mahasiswa program studi dakwah dan komunikasi Universitas Islam Negeri SGD, Bandung.

Dalam konsep pemenuhan kebutuhan melalui media massa, untuk menghasilkan sebuah gratifikasi kebutuhan, Katz dan McQuail memaparkan bahwa: faktor sosial dan psikologis mempengaruhi jenis kebutuhan dan harapannya, begitu juga dengan pola mengkonsumsi sebuah media (Ardianto, Komala, \& Karlinah, 2010).

Tabel. 1 Frekuensi Mendengarkan Radio Mandalla

\begin{tabular}{|c|c|}
\hline Frekuensi Mendengarkan & Presentase \\
\hline 1-2 kali seminggu & $75,6 \%$ \\
3-4 kali seminggu & $13,1 \%$ \\
5-6 kali seminggu & $0 \%$ \\
>6 kali seminggu & $7,3 \%$ \\
\hline Jumlah & $\mathbf{1 0 0} \%$ \\
\hline
\end{tabular}

(Sumber: Hasil Analisis Peneliti)

Berdasarkan tabel 1, mayoritas responden mendengarkan Mandalla UIN 1-2 kali seminggu. Beberapa responden mengaku mereka jarang mendengarkan Radio Mandalla. Alasan yang dikemukakan para responden tersebut lebih karena masalah teknis yang seringnya sibuk mengurus tugas kuliah sehingga tidak lagi memiliki waktu untuk stay tune di Radio Mandalla.

Tabel. 2 Intensitas Mendengarkan Radio Mandalla

\begin{tabular}{|c|c|}
\hline Intensitas Mendengarkan & Presentase \\
\hline$<10$ menit & $19,5 \%$ \\
$11-30$ menit & $22 \%$ \\
$31-45$ menit & $4,9 \%$ \\
Lebih dari satu jam & $7,3 \%$ \\
Tidak tentu & $46,3 \%$ \\
\hline Jumlah & $\mathbf{1 0 0} \%$ \\
\hline
\end{tabular}

(Sumber: Hasil Analisis Peneliti)

Mayoritas responden sebanyak 19 orang mendengarkan Radio Mandalla mengaku tidak tentu saat mendengarkan radio, seperti yang ditunjukkan pada tabel 2. Kemudian yang mendengarkan $<10$ menit sebanyak 8 orang, yang mendengarkan 11-30 menit 9 orang, yang mendengarkan 31-45 menit sebanyak 2 orang, dan yang lebih dari satu jam sebanyak 3 orang.

Durasi menjadi bagian penting sebab durasi dapat menunjukkan keminatan khalayak dalam mengonsumsi sebuah media massa. Untuk responden yang menjawab mendengarkan 
Kajian Jurnalisme

I8) 2549-0559 (cetak) ISSN 2549-1946 (online)

Volume 03 Nomor 01 Tahun 2019

radio lebih dari satu jam bisa menunjukkan bahwa dirinya memiliki peminatan terhadap informasi yang disampaikan oleh radio tersebut. Bagi responden yang mendengarkan radio kurang dari 30 menit bisa dikatakan cukup. Namun, bagi responden yang tidak tentu saat mendengarkan siaran radio dan menjadi pilihan yang paling banyak dipilih, bisa menunjukkan adanya kurang peminatan khalayak dalam mengonsumsi radio karena tidak sesuai dengan motivasi khalayak tersebut. Hal ini juga dapat terlihat dari rentang waktu mengakses sebuah media. Untuk rentang waktu mendengarkan radio, mayoritas responden mendengarkan pukul 08.00-10.00 sebanyak 17 orang, kemudian sebanyak 15 orang mendengarkan pada pukul 10.00-13.00, dan sisanya 9 orang. Kebanyakan kegiatan responden di kampus dimulai dari jam 06.00 hingga jam 13.00, di situlah mereka sedang berada di kampus dan mendengarkan siaran yang sedang mengudara. Selain itu, ketiga jam tersebut dipilih karena disesuaikan dengan kapabilitas Radio Mandalla yang bisa mengudara mulai jam 08.00 WIB hingga 15.00 WIB. Radio Mandalla juga tidak bisa siaran setelah jam 15.00 WIB karena ada regulasi dari kampus UIN SGD.

Tabel 3. Jenis Program yang diakses

\begin{tabular}{|c|c|}
\hline Program yang diakses & Presentase \\
\hline Hiburan & $47,5 \%$ \\
Talkshow & $7,5 \%$ \\
Informasi/berita & $35 \%$ \\
Dakwah & $7,5 \%$ \\
Pendidikan & $2,5 \%$ \\
\hline Jumlah & $\mathbf{1 0 0} \%$ \\
\hline
\end{tabular}

(Sumber: Hasil Analsis Peneliti)

Sedangkan, untuk program yang diakses oleh responden (tabel 3), mayoritas mendengarkan program hiburan, yaitu sebanyak 19 orang. Selain itu, sebanyak 14 orang, responden juga mengakses Radio Mandall untuk mencari atau memperoleh informasi sekitar yang diberitakan oleh Radio Komunitas tersebut. Hanya 3 orang tertarik untuk mendengarkan talkshow, sedangkan hanya 3 orang juga yang tertarik mendengarkan dakwah, dan hanya 1 orang yang tertarik dengan pendidikan. Hiburan menjadi paling tinggi diakses, karena membantu para responden untuk melepaskan penat di tengah-tengah aktivitas kampus. Selain itu, mereka juga mendengarkan informasi/berita dengan tujuan menambah informasi perkawanan agar tidak tertinggal tren.

Tabel 4. Kegiatan yang dilakukan Ketika Mendengarkan Radio

\begin{tabular}{|c|c|}
\hline Kegiatan ketika Mendengarkan Radio & Presentasi \\
\hline Makan & $14,6 \%$ \\
Mengerjakan tugas/belajar & $17,1 \%$ \\
Mengakses media sosial & $31,7 \%$ \\
Lainnya & $36,6 \%$ \\
\hline \multicolumn{2}{|c|}{ Jumlah } \\
(Sumber: Hasil Analisis Peneliti)
\end{tabular}

http://jurnal.unpad.ac.id/kajian-jurnalisme 
101 | Kajian Jurnalisme

ISSN 2549-0559 (cetak) ISSN 2549-1946 (online)

Volume 03 Nomor 01 Tahun 2019

Dalam mendengarkan radio seringkali dilakukan sambil melakukan kegiatan lain, hal ini juga terjadi pada pendengar Radio Mandalla. Hal ini digambarkan pada tabel 4, mayoritas responden, sebanyak 15 orang mendengarkan Radio Mandalla sambil melakukan kegiatan lain, misalnya sambil mengobrol dengan teman dan 13 responden mengakses media sosial sembil mendengarkan Radio Mandalla. Kegiatan lainnya yang dilakukan oleh 7 orang responden adalah mendengarkan radio sambil mengerjakan tugas, dan 6 orang lainnya melakukannya sambil makan.

Melihat salah satu karakteristik radio adalah media auditif, yang artinya memungkinkan siaran radio bisa dinikmati sambil mengerjakan aktivitas lain, tanpa mengganggu aktivitas tersebut (Ambarwati, Santosa, Nugroho, \& Lailiyah, 2016). Pendengar radio tidak tetap di depan layar, seperti halnya menonton televisi. Ini berarti mendengar radio dapat dilakukan sembari melakukan hal-hal lainnya, berpindah tempat, tetapi tetap dengan konsentrasi tinggi. Ini berarti lebih banyak waktu yang dapat dihabiskan untuk mendengarkan sementara pekerjaan-pekerjaan lain diselesaikan. Ini juga berarti bahwa makin banyak pendengar dijangkau sementara mereka bekerja (Romli, 2009:16-17).

Tabel 5. Lokasi Mendengarkan Radio

\begin{tabular}{|c|c|}
\hline Lokasi Mendengarkan Radio & Presentase \\
\hline Di kampus & $61 \%$ \\
Di rumah & $26,8 \%$ \\
Di jalan & $2,4 \%$ \\
Di tempat lain & $9,8 \%$ \\
\hline Jumlah & $\mathbf{1 0 0 \%}$ \\
\hline
\end{tabular}

(Sumber: Hasil Analisis Peneliti)

Mengingat karakteristik Radio Komunitas, yaitu jangkauan siarannya terbatas, tabel 5 menunjukkan bahwa mayoritas responden mendengarkan Radio Mandalla ketika mereka di kampus, sekitar 25 orang. Responden yang jarak tempat tinggalnya tidak jauh dari kampus UIN SGD, biasanya masih dapat mengakses dari rumah. Dan yang lainnya mendengarkan di tempat lain, atau sedang di jalan sambil menemani di perjalanan. Hal itu disebabkan karena Radio Mandalla hanya bisa didengarkan lewat audio lane, handphone, dan radio konvensional. Hal ini menjadi lumrah apabila mereka kebanyakan mendengarkan Radio Mandalla di kampus, karena kegiatan responden sehari-hari yang mayoritas lebih banyak menghabiskan waktunya di kampus UIN SGD. Mayoritas responden mendengarkan Radio Mandalla menggunakan handphone sebanyak 38 orang dan sisanya 3 orang mendengarkan melalui radio konvensional. Berdasarkan pemaparan responden, siaran Radio Mandalla yang didengarkan melalui audio lane di kampus kurang jelas dan kurang menarik, sehingga pilihan yang paling mudah adalah mengakses melalui handphone. Dengan kemajuan teknologi komunikasi dan informasi membuat radio tidak hanya bisa didengarkan lewat pesawat radio, tapi bisa juga melalui handphone.

Sebanyak 21 orang responden memilih sekedar mendengarkan program yang sedang mengudara, yang kemudian sejumlah 15 orang cukup aktif berinteraksi dengan meminta atau request lagu, dan sisanya 5 orang mengikuti program interaksi, seperti talkshow. Menurut 
Kajian Jurnalisme

18) 8 N 2549-0559 (cetak) ISSN 2549-1946 (online)

Volume 03 Nomor 01 Tahun 2019

Masduki, pendengar radio terdiri dari pendengar yang aktif dan pasif (Masduki, 2004). Pendengar aktif artinya mereka secara reguler tak terbatas mendengarkan siaran radio, apa pun, di manapun, dan aktif berinteraksi melalui telepon. Radio menjadi sahabat utama, tidak hanya pada waktu luang. Kemudian pendengar pasif, yakni pendengar yang mendengarkan radio hanya untuk didengar sembari mengisi waktu luang dan menghibur diri. Dalam tabel di atas menunjukkan bahwa responden Radio UIN digolongkan ke dalam responden pasif karena mereka lebih dominan sekedar mendengarkan siaran radio.

\section{Motif Mendengarkan Radio Mandalla}

Khalayak pada dasarnya menggunakan media massa berdasarkan motif-motif tertentu. Motif didefinisikan sebagai kebutuhan, keinganan, dorongan, atau gerak hati dalam individu. Motif-motif diarahkan kepada tujuan-tujuan, yang terjadi dengan sadar atau di bawah sadar (Kriyantono, 2014, p. 203). Pada dasarnya motif-motif atau kebutuhan-kebutuhan merupakan sebuah dorongan utama daripada kegiatan audiens menggunakan media. Ada berbagai kebutuhan yang dipuaskan oleh media khususnya media massa, ketika ingin mencari kesenangan, media massa dapat memberikan hiburan, ketika mengalami goncangan batin, media massa dapat memberikan kesempatan untuk melarikan diri dari kenyataan, dan ketika kesepian media massa berfungsi sebagai sahabat.

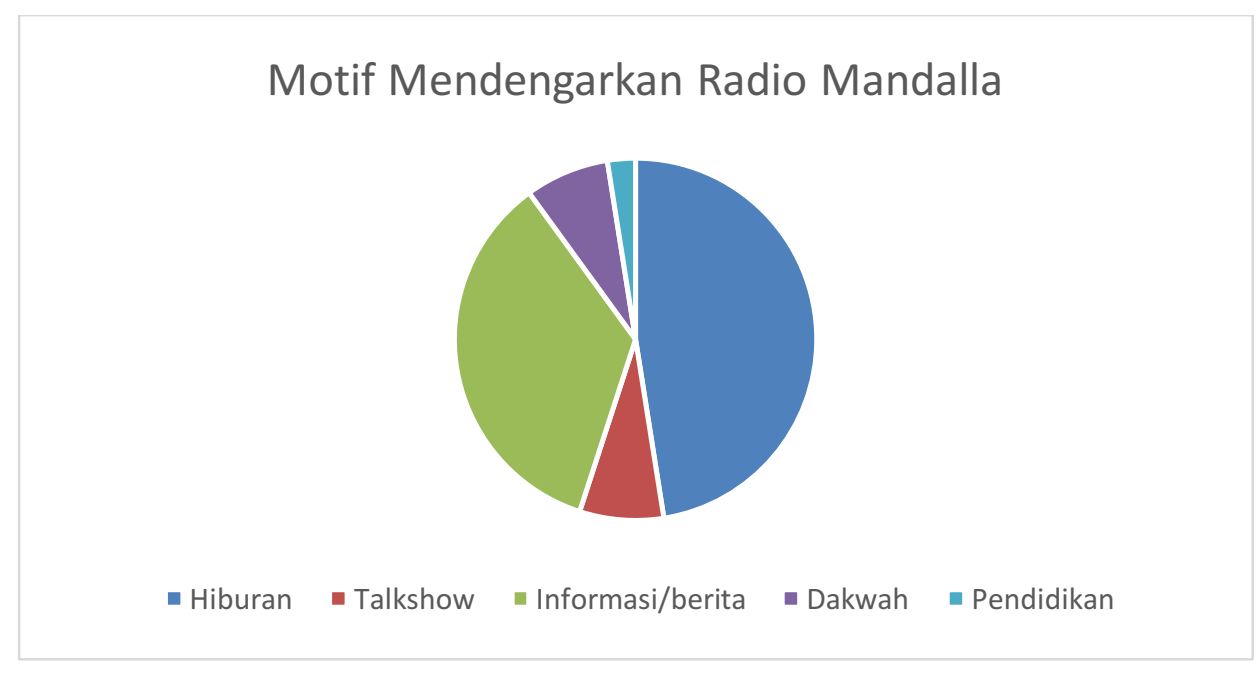

Gambar 1 Motif Pendengar Mendengarkan Radio Mandalla

(Sumber: Hasil Analisis Peneliti)

Dalam konteks penelitian ini, motif khalayak pendengar menggunakan Radio Mandalla untuk memenuhi kebutuhan akan hiburan, informasi, dan pendidikan. Khalayak mendengarkan radio untuk melepas penat, memperbaiki suasana hati, mengisi waktu luang, mengetahui tren yang terjadi, menambah wawasan tentang dakwah, dan sebagainya. Sebagai radio dakwah, $35 \%$ pendengarnya mendengarkan Radio Mandalla untuk motif informasi. Setiap pagi, radio mandalla mempunyai program informasi mengenai hal-hal yang terjadi di dalam kampus 
103 | Kajian Jurnalisme

ISSN 2549-0559 (cetak) ISSN 2549-1946 (online)

Volume 03 Nomor 01 Tahun 2019

Universitas Islam Negeri Sunan Gunung Djati. Maka dari itu 42\% pendengar Radio Mandalla, mendengarkan radio tersebut di pagi hari, pukul 08.00-10.00 adalah pendengar terbanyak. Acara pagi ini tidak hanya berfokus menyiarkan berita di kampus saja, terkadang diisi dengan berita nasional yang sedang menjadi berita hangat, serta berita atau informasi tentang keilmuan islam yang mengikuti perkembangan zaman, tidak kaku, tapi tetap bernuasa dakwah.

Selain program pagi yang menyiarkan tentang informasi lingkungan kampus dan sekitar, Radio Mandala juga mempunya program hiburan. Hal ini terlihat dari mayoritas (sebanyak 48\%) pendengar Radio Mandalla mendengarkan Radio tersebut untuk hiburan. Radio Mandalla menjalankan salah satu fungsi media massa, yaitu to entertain (menghibur). Sebagai radio yang mengklaim media dakwah, jenis hiburan yang disajikan oleh Radio Mandalla adalah siaran yang menyajikan tentang ensiklopedia Islam. Acara ini dikemas dalam Senandung Musik Islami, biasanya bercerita tentang tokoh-tokoh Islam yang sukses sehingga dapat menginspirasi pendengar Radio Mandalla. Karena sebagian besar pendengar Radio Komunitas ini, yaitu sekitar $71 \%$ berusia paling muda 17 tahun, maka acaranya pun dikemas untuk dapat menarik pendengar muda.

Media massa, dalam hal ini radio komunitas kampus, dianggap berusaha memenuhi motif khalayak. Jika motif khalayak terpenuhi maka kebutuhan khalayak yang terpenuhi sama dengan khalayak puas setelah menggunakan media. Khalayak merasa puas dengan konten yang disajikan oleh Radio Mandalla. Hal ini terbukti dengan hasil survei yang menunjukkan lebih dari 55\% khalayak memilih opsi setuju menggunakan Radio Mandalla sebagai media hiburan, informasi, dan pendidikan. Berarti, diketahui bahwa pemenuhan akan kebutuhan tersebut sudah dipenuhi dengan baik.

\section{Tingkat Kepuasan Khalayak Terhadap Radio Mandalla}

Media komunitas menurut Denis McQuail, pertama memberikan pelayanan informasi isu-isu dan problem universal tidak sektoral dan primordial (McQuail, 2011). Radio Mandalla memberikan informasi-informasi yang dibutuhkan oleh khalayaknya. Misalnya, menyediakan program Salam Silahturahmi Kampus (SSK) yang isinya membahas tentang tips-tips untuk anak kosan, talkshow tentang informasi, dan menyajikan lagu-lagu yang sedang tren di kalangan mahasiswa.

Kedua, pengembangan budaya interaksi yang pluralistik. Misalnya, di program Horison Islami yang membahas seputar dunia Islam. Di dalam program tersebut, penyiar menghadirkan beberapa narasumber untuk membahas tentang suatu tema dan memberikan beberapa pandangan yang berbeda-beda. Di sini, pendengar juga bisa menyampaikan pandangannya lewat call in, seperti SMS atau telfon langsung ke penyiar yang sedang on air.

Ketiga, penguatan eksistensi kelompok minoritas dalam masyarakat. Hal tersebut juga telah dilakukan Radio Mandalla lewat program SSK yang mengundang suatu komunitas tertentu untuk memperkenalkan dirinya. Karenanya, khalayak menjadi tahu bahwa ada komunitas atau kelompok tertentu yang menarik untuk diketahui.

Keempat, bentuk fasilitasi atas proses menyelesaikan masalah menurut cara pandang lokal. Sayangnya, di fungsi keempat ini khalayak mengaku jarang menggunakan Radio 
Kajian Jurnalisme

18)4N 2549-0559 (cetak) ISSN 2549-1946 (online)

Volume 03 Nomor 01 Tahun 2019

Mandalla untuk menyelesaikan masalah. Beberapa responden mengatakan mereka hanya menggunakan Radio Mandalla untuk pemenuhan kebutuhan akan informasi dan hiburan, bukan untuk menyelesaikan masalah.

Radio Komunitas hadir untuk melayani kepentingan komunitasnya. Radio komunitas dibiayai juga oleh komunitas. Pada akhirnya radio komunitas adalah dari, untuk, oleh komunitas. Penyiaran pada radio komunitas mewakili semua lapisan masyarakat yang terdapat dalam komunitas yang bersangkutan secara merata dan demokratis (Issetiabudi, 2012). Hasil penelitian terhadap Radio Komunitas Kampus Mandalla FM, responden menganggap Radio Komunitas Kampus Mandalla merupakan media massa yang bisa memenuhi kriteria sesuai dengan definisi yang disampaikan oleh McQuail dan Vogt. Hasil juga menunjukkan bahwa Radio Mandalla sudah menjalankan peran dan fungsinya sesuai dengan konsep dasar uses and gratification yang diungkapkan oleh Ardianto, studi uses and gratification memusatkan perhatian pada penggunaan media untuk mendapatkan kepuasan atas kebutuhan seseorang, dalam hal ini komunitas dari radio komunitas kampus (Ardianto et al., 2010). Jadi, bisa dikatakan ketika audiens sudah merasa puas, berarti peran dan fungsi radio komunitas telah berhasil menjalankan tugasnya.

\section{Simpulan}

Pola konsumsi khalayak pendengar terhadap Radio Mandalla, baik dari segi frekuensi, curahan waktu, maupun intensitas mendengar, dapat digolongkan pada kategori kurang. Terdapat $75,6 \%$ dari total responden mendengarkan program di radio tersebut 1-2 kali dalam seminggu. Demikian pula pada curahan waktu dan intensitas mendengar, terlihat kecenderungan yang sama, yaitu sebanyak 46,3\% responden mencurahkan rata-rata kurang dari 10 menit setiap harinya untuk mendengarkan program di radio tersebut dan $36,6 \%$ responden mengaku juga melakukan aktivitas lain saat mendengarkan Radio Mandalla. Selain itu, ditemukan bahwa program yang paling banyak didengarkan responden adalah program hiburan. Sebaliknya, program yang paling sedikit penggemarnya adalah pendidikan.

Mayoritas responden menilai produk Radio Mandalla menurut isi dan kemasannya cukup bagus, baik dari segi keluasan konten, relevansi topik, akurasi, keseimbangan, dan cara penyiar menyampaikan program siarannya. Hal ini ditunjukkan oleh data yang lebih dari 55\% responden memberi penilaian yang cukup tinggi terhadap isi dan kemasan radio komunitas kampus tersebut. Lebih dari 50\% responden memberi nilai cukup tinggi pada peran dan fungsi radio komunitas 107.8 Mandalla FM. Hal tersebut dikarenakan, responden menggunakan radio Mandalla sebagai media untuk mencari informasi, sebagai media interaksi yang pluralistik, dan penguatan eksistensi kelompok minoritas dalam masyarakat.

\section{Daftar Pustaka}

Ambarwati, D. R., Santosa, H. P., Nugroho, A., \& Lailiyah, N. (2016). Pengaruh Strategi Program Siaran dan Kompetensi Komunikasi Penyiar terhadap Minat Mendengarkan Radio 90,2 Trax FM Semarang. Interaksi Online, 4(1). 
105 | Kajian Jurnalisme ISSN 2549-0559 (cetak) ISSN 2549-1946 (online)

Volume 03 Nomor 01 Tahun 2019

Ardianto, E., Komala, L., \& Karlinah, S. (2010). Komunikasi Massa:Suatu Pengantar (Edisi Revi). Bandung: Simbiosa Rekatama Media.

Blumler, J. G. (1979). The role of theory in uses and gratifications studies. Communication Research, 6(1), 9-36. https://doi.org/10.1177/009365027900600102

Bungin, B. (2011). Penelitian Kualitatif: Komunikasi, Ekonomi, Kebijakan Publik, Dan Ilmu Sosial Lainnya. In Kencana. https://doi.org/10.1002/jcc.21776

Gazali, E. (2002). Penyiaran Alternatif tapi Mutlak: Sebuah Acuan tentang Penyiaran Publik dan Komunitas (E. Gazali, Ed.). Jakarta: Jurusan Ilmu Komunikasi FISIP UI.

Haryanto, I., \& Ramdojo, J. J. (2009). Dinamika Radio Komunitas (H. Suranto, Ed.). Jakarta: Kerja sama Lembaga Studi Pers dan Pembangunan [dengan] Yayasan Tifa.

Issetiabudi, D. E. (2012). Motivasi Penyiar Bekerja di Radio Komunitas (Studi Deskriptif Kualitatif Motivasi Penyiar Bekerja di Radio Komunitas Balai Budaya Minomartani 107.9 FM). Universitas Atma Jaya Yogyakarta.

Kriyantono, R. (2014). Teknik Praktis Riset komunikasi. Jakarta: Prenada Media Group.

Masduki. (2004). Menjadi Broadcaster Profesional. Yogyakarta: Pustaka Populer LKiS.

McQuail, D. (2011). Teori Komunikasi Massa (6th ed.). Salemba Humanika.

Nasution, F. (2012). Radio Komunitas Sebagai Media Dakwah. Hikmah, VI(1), 43-55.

Pendit, P. L. (2003). Penelitian ilmu perpustakaan dan informasi: suatu pengantar diskusi epistemologi dan metodologi. Jakarta: Jurusan Ilmu Perpustakaan-Fakultas Sastra, Universitas Indonesia (JIP-FSUI).

Prasetyo, B., \& Jannah, L. M. (2008). Metode Penelitian Kuantitatif: Teori dan Aplikasi. Jakarta: Raja Grafindo Persada.

Rachmiatie, A. (2007). Radio Komunitas: Eskalasi Demokratitasi Komunikasi. Bandung: Simbiosa Rekatama Media.

Rakhmat, J. (2014). Metode Penelitian Komunikasi Dilengkapi Contoh dan Analisis Statistik. Bandung: Remaja Rosdakarya.

Romli, A. S. M. (2009). Dasar-dasar Siaran Radio: Basic Announcing. Bandung: Nuansa.

Sjuchro, D. W. (2017). Pelaksanaan Regulasi Penyiaran di Daerah, Studi Di Sepuluh Provinsi. Jurnal Kajian Jurnalisme, 1(1). https://doi.org/10.24198/kj.v1i1.12226

Sjuchro, D. W. (2018). Gelombang Demokrasi di Langit Katapang; Radio Komunitas dan Good Governance: Sebuah Praktik Civil Society (Cet. 1). Yogyakarta: Titah Surga.

Susilo, E. A. (2016). Mengoptimalkan peran radio komunitas sebagai ruang publik dan media interaksi komunikasi pemangku kepentingan. Journal of Nomosleca, 2(1).

Tanta, I., Mihovilović, M., \& Sablić, Z. (2014). Uses and Gratification Theory - Why Adolescents Use Facebook? Medijska Istraživanja, 20(2), 85-110.

Wahyudi, J. B. (1996). Dasar-dasar Jurnalistik Radio dan Televisi (1st ed.). Jakarta: PT. Pustaka Utama Grafiti. 